\title{
Apolipoprotein E and herpes virus diseases: herpes simplex keratitis
}

\author{
Woan-R u Lin ${ }^{1}$, A ndrew B Tullo ${ }^{2}$ and R uth F Itzhaki ${ }^{1}$ \\ ${ }^{1}$ M olecular Neurobiology L aboratory, Department of O ptometry and Vision Sciences, UM IST \\ ${ }^{2} \mathrm{D}$ epartment of $\mathrm{O}$ phthalmology, Central M anchester $\mathrm{H}$ ealthcare NHS Trust, M anchester R oyal E ye Hospital, \\ $M$ anchester, UK
}

\begin{abstract}
O ur previous studies showed that herpes simplex type 1 virus (H SV 1 ) is present in a high proportion of the brain of elderly normal people and A Izheimer's disease (A D ) patients. We subsequently discovered that the combination of HSV 1 in brain and carriage of the type 4 allele of the gene for apolipoprotein $E(a p o E-\varepsilon 4)$ is a strong risk factor for $A D$, and also that apoE - $\varepsilon 4$ is a strong risk factor for herpes labialis. In this study we have examined apoE genotypes of sufferers from another disorder caused by HSV 1, namely, herpes simplex keratitis (H SK), to find if an apoE allele is involved in the disorder. In $46 \mathrm{H} \mathrm{SK}$ patients the apoE - $\varepsilon 4$ allele frequency was $15 \%$-the same as that found in 238 unaffected controls. The apoE - $\varepsilon 2$ allele frequency was $13 \%$ - higher than the value of $7 \%$ for unaffected people, but the difference is not statistically significant.
\end{abstract}

Keywords: herpes keratitis; apolipoprotein E; herpes simplex type 1 virus

\section{Introduction}

The type 4 allele of the gene for apolipoprotein $E$ $(a p o E-\varepsilon 4)$ is a risk factor for cold sores. ${ }^{1,2}$ More importantly, herpes simplex type 1 virus (HSV 1 ) is a risk factor for A Izheimer's disease (A D) when present in brain of possessors of an apoE- $\varepsilon 4$ allele, the combination of virus and genetic factor being found in almost two thirds of the A D patients studied. ${ }^{1,2} \mathrm{O}$ the basis of these results in PNS and CNS disease, the apoE genotype of sufferers from a further variant of HSV disease-herpes simplex keratitis (HSK)-was investigated, to determine whether or not the disorder is

Correspondence: Professor Ruth Itzhaki, Molecular Neurobiology Laboratory, Department of Optometry and Vision Sciences, UMIST, M anchester M601QD, UK. Tel: $441612003879 ; \quad F a x: \quad 441612004433 . \quad$ E-mail: ruth.itzhaki@umist.ac.uk

R eceived 6 July 1998; revised 4 December 1998; accepted 10 D ecember 1998 associated with a specific apoE allele. HSK is the leading infectious cause of corneal blindness in the developed world.

\section{Subjects and Methods}

Forty-six HSK patients comprised 27 males, mean age 58,
range $18-89$, and 19 females, mean age 60 , range $33-87$. They
were diagnosed on the basis of chronic, unilateral recurrent
disease characterised by dendritic or geographical keratitis,
and in some cases they progressed to stromal involvement.
Non-H SK sufferers ('controls') comprised volunteers from
the U niversity and from two local hospitals ( ${ }^{2}$ (referred to as
'volunteer' and 'population' groups, respectively). There were
101 males, mean age 37.5 years, 132 females, mean age
36.5 years, and five of unspecified sex. A II patients and
controls gave consent for a single blood sample to be taken
for research purposes.
A polipoprotein E genotypes were determined by preparing
D NA from peripheral leucocytes obtained from patients'
blood, ${ }^{1}$ and amplifying a 227 bp sequence in the apoE gene, 
followed by digestion with cfol and electrophoresis of the digestion products. ${ }^{3}$

\section{Results and Discussion}

Figure 1 shows typical results of agarose gel electrophoresis after PCR. Table 1 displays the apoE genotypes and the allele frequencies of the HSK patients. The apoE- $\varepsilon 4$ allele frequency of the HSK patients is $15 \%$, which is identical to that of our normal population value of $15 \%$ ( $P>0.5, \chi^{2}$ test). The apoE - $\varepsilon 2$ allele frequency is $13 \%$, which is higher than our normal population value of $7 \%$ but does not reach statistical significance ( $P=0.06, \chi^{2}$ test). Of the HSK sufferers, $33 \%(15 / 46)$ reported that they suffer from cold sores. This proportion is higher than that of our 'controls' $(24 \%)$, though not significantly so.

The apolipoproteins comprise a class of proteins responsible for transporting lipids in plasma. They are involved also in the repair response to tissue injury in various organs, including nerve injury and regeneration. ${ }^{4} \mathrm{~A}$ ttachment of apoE $s$ to cells, ${ }^{5}$ and also that of $\begin{array}{lllllllllll}1 & 2 & 3 & 4 & 5 & 6 & 7 & 8 & 9 & \mathrm{~B} & \mathrm{M}\end{array}$

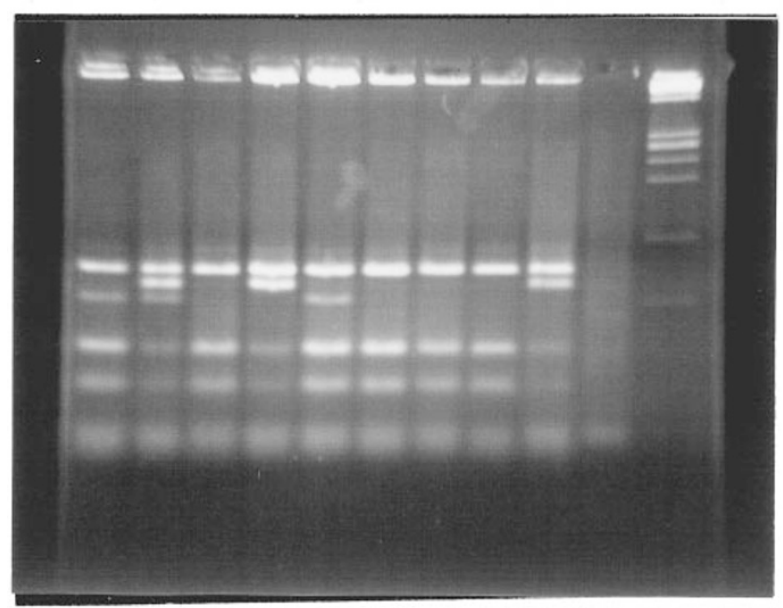

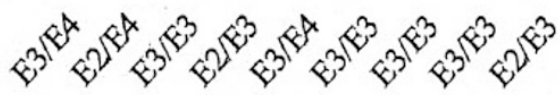

Figure 1 A garose gel electrophoresis of amplified products after PCR, for apoE genotyping of HSK patients. $M$ is a molecular weight marker ( $\Phi$ X 174, $\mathrm{H}$ ael II-digested) and B is a reagent blank

Table 1 A polipoprotein E genotypes of HSK patients and of local 'normal' subjects

\begin{tabular}{|c|c|c|c|c|c|}
\hline & & \multicolumn{2}{|c|}{$\begin{array}{c}\text { HSK } \\
\text { patients }\end{array}$} & \multicolumn{2}{|c|}{$\begin{array}{c}\text { M anchester 'Control' } \\
\text { subjects }\end{array}$} \\
\hline & & \multirow[t]{2}{*}{ Total } & \multirow{2}{*}{$\begin{array}{l}33 \% \\
\text { With } \\
\text { cold sores }\end{array}$} & \multicolumn{2}{|c|}{ Total } \\
\hline & & & & $\begin{array}{l}\text { 'population' } \\
\text { group }\end{array}$ & $\begin{array}{l}\text { University } \\
\text { 'volunteer' group }\end{array}$ \\
\hline \multirow[t]{2}{*}{ Genotype } & $\begin{array}{l}\text { E 2/E } 2 \\
\text { E 2/E } 3 \\
\text { E 2/E } 4 \\
\text { E 3/E } 3 \\
\text { E 3/E } 4 \\
\text { E 4/E } 4\end{array}$ & $\begin{array}{r}1 \\
8 \\
2 \\
24 \\
10 \\
1\end{array}$ & $\begin{array}{l}0 \\
3 \\
1 \\
9 \\
2 \\
0\end{array}$ & $\begin{array}{r}1 \\
9 \\
3 \\
54 \\
30 \\
0\end{array}$ & $\begin{array}{r}1 \\
13 \\
6 \\
78 \\
40 \\
3\end{array}$ \\
\hline & Total & 46 & 15 & 97 & 141 \\
\hline \multirow[t]{2}{*}{ A llele number } & $\begin{array}{l}\text { E } 2 \\
\text { E } 3 \\
\text { E } 4\end{array}$ & $\begin{array}{l}12 \\
66 \\
14\end{array}$ & $\begin{array}{r}3 \\
24 \\
3\end{array}$ & & \\
\hline & Total & 92 & 30 & & \\
\hline A llele frequency & $\begin{array}{l}\text { A poE } 2 \% \\
\text { A poE } 3 \% \\
\text { A poE } 4 \%\end{array}$ & $\begin{array}{l}13.0 \\
71.7 \\
15.2\end{array}$ & $\begin{array}{l}10.0 \\
80.0 \\
10.0\end{array}$ & $\begin{array}{r}7.3 \\
77.9 \\
14.8\end{array}$ & \\
\hline
\end{tabular}

an the 'volunteer' survey, cold sore sufferers were specifically sought, so the proportion of sufferers was high (48\% ) and ther efore non-representative of the general population. To obtain ' $M$ anchester' allele frequency values using as large a number of people as possible, values for the 'volunteer' group and the 'population' group were combined, as described in footnote $b$.

${ }^{\mathrm{b}}$ The proportion of cold sore sufferers in the population survey, which was found to be $24 \%$, was used to calculate appropriate percent allele frequencies for the U niversity 'volunteers', i.e., values for the U niversity sufferers were multiplied by 0.24 and for the non-sufferers by 0.76 , and were then added together. The frequencies for the combined U niversity plus population groups were then calculated on a weighted basis, i.e., by correcting each percent allele frequency for the relative numbers in the two groups. 
H SV $1,{ }^{6}$ is mediated by heparan sulphate proteoglycans in the cell membrane. In neuronal cells in culture the amount of apoE 4 that enters the cells is less than that of apoE $3 .{ }^{7}$ We have therefore suggested a possible mechanism for the combined risk conveyed by HSV 1 and apoE- $\varepsilon 4$ : that on stress or immunosuppression, reactivation of the latent HSV 1 occurs in brain (if present) and the number of cells infected by the virus, and hence the extent of damage, is greater in apoE $-\varepsilon 4$ possessors than in those with the other alleles. ${ }^{1}$

The lack of involvement of apoE - $\varepsilon 4$ in H SK contrasts with its apparent role in $A D$ and in herpes labialis. It is a strong risk factor in both-in the former when combined with HSV 1 in brain, and in the latter when combined with HSV 1 in the PNS. ${ }^{1,2}$ (In the A D study, the odds ratio for apoE - $\varepsilon 4$ was $12.0(\mathrm{Cl} 3.44-42.06)$ for HSV 1-positive patients and 1.57 (OR $0.32-7.63$ ) for H SV 1-negative patients. ${ }^{2}$ ) On the basis of our findings in $A D$ and in herpes labialis, we postulated that the combination of HSV 1 and apoE- $\varepsilon 4$ damages the nervous system. Corneal cells are mainly fibroblast-like, and a study of fibroblasts in culture showed that fewer apoE 2 molecules than the other isoforms entered the cells. $^{8} \mathrm{O}$ ur present results on HSK indicate that apoE $\varepsilon 4$ is not involved in this disorder but that the apoE- $-\varepsilon 2$ allele frequency increases slightly. This is consistent with the concept of a non-neuronal site of latency, and hence of reactivation, in this disorder. ${ }^{9} \mathrm{~A}$ poE 2 might compete less effectively than the other apoE isoforms with HSV 1 for attachment to corneal cells, and hence entry of the virus and subsequent damage could be greater in apoE - $\varepsilon 2$ possessors. A Iternatively, the receptors in corneal cell membranes might differ from those of neuronal cells in respect of attachment to apoE s and HSV 1.

\section{Acknowledgements}

We thank the Wellcome Trust for a Sir Henry Wellcome A ward for Innovative R esearch and R emedi for a grant, M rs J Graham for assistance, and Dr B Faragher for statistical advice.

\section{References}

1 Itzhaki RF, Lin WR, Shang D, Wilcock GK, Faragher B, Jamieson $G A$ : H erpes simplex virus type 1 in brain and risk of A Izheimer's disease. $L$ ancet 1997; 349: 241-2.

2 Lin WR, G raham J, M acG owan S, Wilcock G K, I tzhaki R F: A Izheimer's disease, herpes virus in brain, apolipoprotein E 4 and herpes labialis. A Iz Repts 1998; 1:

3 Wenham PR, Price WH, Blundell G: A polipoprotein E genotyping by one-stage PCR. Lancet 1991; 337: 1158-1159.

4 M ahley RW: A polipoprotein E : structure and function in lipid metabolism and neurobiology. In: R osenberg RN Prusiner SB, DiM auro S, B archi RL (eds). The Molecular and $\mathrm{G}$ enetic Basis of Neurological Disease. Butterworth H einemann: Newton, M A , 1997, pp 1037-1050.

5 J i ZS, Fazio S, L ee Y L, M ahley RW: Secretion-capture role for apolipoprotein $\mathrm{E}$ in remnant lipoprotein metabolism involving cell surface heparan sulfate proteoglycans. J Biol Chem 1994; 269: 2764-2772.

6 H erold B C, WuD unn D, Soltys N, Spear PG : G lycoprotein $C$ of herpes simplex virus type 1 plays a principal role in the adsorption of virus to cells and in infectivity. J Virol 1991; 65: 1090-1098.

7 Nathan BP, Chang K-C, Bellosta S et al: The inhibitory effect of apolipoprotein E4 on neurite outgrowth is associated with microtubule depolymerization. J B iol Chem 1995; 270: 19791-19799.

8 Weisgraber $\mathrm{KH}$, Innerarity TL, Mahley RW: A bnormal lipoprotein receptor-binding activity of the human $E$ apoprotein due to Cysteine-A rginine interchange at a single site. J Biol Chem 1982; 257: 2518-2521.

9 Cook SD, Hill JH: H erpes simplex virus: molecular biology and the possibility of corneal latency. Survey 0 pthalmol 1991; 36: 140-148. 